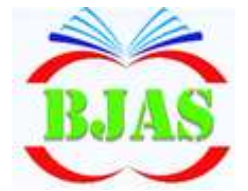

Available online at http://bjas.bajas.edu.iq

https://doi.org/10.37077/25200860.2021.34.2.18

College of Agriculture, University of Basrah

ISSN $1814-5868$

Basrah J. Agric. Sci., 34(2), 240-252, 2021

\section{Basrah Journal \\ of Agricultural \\ Sciences \\ $, \ldots, \ldots, 1, \ldots, \ldots$}

E-ISSN: 2520-0860

\title{
Efficacy of Ozone Gas against All Stages of Red Flour Beetle, Tribolium castaneum (Herbst) (Coleoptera: Tenebrionidae) at Different Temperatures and Exposure Periods
}

\author{
Mohammed S. Al-Emara ${ }^{1 *}$; Aqeel A. Alyousuf ${ }^{2}$ \& Mohammed H. Abass ${ }^{2}$ \\ ${ }^{1}$ State Company for Foodstuff Trading, Ministry of Trade, Iraq \\ ${ }^{2}$ Department of Plant Protection, College of Agriculture, University of Basrah, Iraq \\ *Correspondence, author email: malemara@yahoo.com
}

Received 9th March 2021; Accepted $3^{\text {rd }}$ June 2021; Available online 5 November 2021

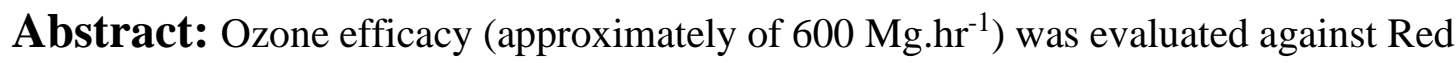
Flour Beetle's (RFB, Tribolium castium (Herbst)) eggs, larvae, pupae and adults at different temperatures $\left(35,40\right.$ and $\left.45^{\circ} \mathrm{C}\right)$ and exposure times $(1,2,4,6,8,10$ hours) under laboratory. The control treatments included above thermal levels without ozone at the mentioned exposure periods. The results indicated ozone effectively suppressed hatching with increasing temperature. The hatch egg rates was reduced to $0 \%$ in the treated treatments after $10 \mathrm{~h}$ at $45^{\circ} \mathrm{C}$. However, mortality rates of RFB were increased with maximizing of the exposure time to ozone. After 10-h exposure to ozone at the lowest temperature $35^{\circ} \mathrm{C}$, complete mortality $(100 \%)$ or few survivals of RFB were recorded in the susceptible stages (larvae and adults). Also, the complete mortality of adults and larvae resulted after an exposure to ozone at $40^{\circ} \mathrm{C}$ for 10 hours, compared than the high survival rates at the pest's stages at 30 and $40^{\circ} \mathrm{C}$, even after 10 hours of monitoring time. However the exposure time which is required to $100 \%$ mortality was decreased to 4 hours at $45^{\circ} \mathrm{C}$, comparing to the thermal treatment only (control) which needed more time $(6 \mathrm{~h})$ for $100 \%$ of mortality. In conclusion, ozone application showed the efficacy on the mortality at all stages of RFB and the temperature was a potential factor enhancing the application of ozone for RFB control.
\end{abstract}

Keywords: Ozone gas, Tribolium castaneum, Non chemical control, survival.

\section{Introduction}

Wheat is one of the first grains known to people and is currently one of the most important food staples for humanity, which is the main source of carbohydrates and about $20 \%$ of the total dietary calories worldwide (Shiferaw et al., 2013; Juárez. et al., 2021). Stored product insect pests are mainly responsible for heavy losses of grain through their feeding behavior, gradual gathering of the heat and moisture, reducing grain quality and germination, as well as increasing microbial contamination (Tefera et al., 2011; Kumar \& Kalita, 2017). Red Flour Beetle (RFB) Tribolium castaneum is one of most important stored product insect pests 


\section{Al-Emara et al. / Basrah J. Agric. Sci., 34(2), 240-252, 2021}

worldwide. It is a primary pest of flour and other grain products, and a secondary pest of stored wheat, causing severe damage to these grains and their food products (Iram et al., 2013; Aboelhadid \& Youssef, 2021). Both larvae and adults feed on flours and broken grains (Karunakaran et al., 2004; Rees, 2004; Mariadoss \& Umamaheswari, 2020).

Controlling the stored product insect pests has become enormously difficult, due to many reasons such as developing of the pesticide resistance in some insects. Whalon et al. (2008) reported that the rusty flour beetle showed a high level of resistance to the action of pesticides up to 200 folds. To reduce acute and chronic risks from the use of insecticides, it has prompted radical changes in pest management strategies and the substitution of pesticides with effective but less dangerous substances (Pretty \& Bharucha, 2015). Ozonation is one of the promising alternatives against wide range of insects of stored products such as $T$. confusum and Oryzaephilus surinamensis, Sitophilus zeamais, Rhyzopertha dominica (Kells et al., 2001; Mason et al., 2006, Pimentel et al., 2007; Sousa et al. 2008; Tiwari et al., 2010; Sabeat, 2017; Kopacki et al, 2021; Seyedabadi et al, 2021). Ozone $\left(\mathrm{O}_{3}\right)$ is extremely oxidative and environmentally friendly because of its decomposing rapidly to oxygen without leaving any residue side effects on the treated grain (Mendez et al., 2003; Khadre et al., 2001). It is used in many fields such as water purification, bleaching and sterilization of medical devices, as well as for removing odors, colors, pesticides, inorganic materials, and organic compounds (Forney et al., 2007; Wei et al., 2007). Moreover, it is easy to generate directly, that eliminates the need to store or dispose of dangerous chemicals (Isikber \& Öztekin, 2009).
The objective of this study was to evaluate the ozonation against Red flour beetle Tribolium castaneum (Herbst) (Coleoptera: Tenebrionidae) at different temperatures and exposure time.

\section{Materials \& Methods}

\section{Tribolium castaneum colony}

Red flour beetle $T$. castaneum was obtained from the General Company for Grain Trading, Branch of Basrah; 30 pairs of sex-segregated adults $(ㅈ ㅜ)$ were used to maintain the culture of RFB. The colony was maintained in sterilized $500 \mathrm{ml}$ glass jars filled with wheat flour and 5\% yeast powder as a source of vitamin B1 (Sial et al., 2017) at $28 \pm 2^{\circ} \mathrm{C}$ and $65 \pm 5 \%$ relative humidity in a growth chamber (Binder, Germany) Several pairs of adults were reared to get eggs by removing the parent beetles after one day from ovipositing. The eggs were monitored daily to obtain the first instar-larvae. Pupae were separated daily from the colony and sex segregated. Females and males were distinguished by examining the end of the abdomen of virgin beetles under a microscope; they have a pair of abdominal appendages which are larger in females than in males (Fedina \& Lewis 2006; Beeman et al, 2009). The colony of offspring was maintained under the same previous conditions. The insect was identified at Research Center and Natural History Museum/University of Baghdad.

\section{Bioassays}

The treatments included exposure and nonexposure to ozone at different temperatures $\left(35,40\right.$ and $\left.45^{\circ} \mathrm{C}\right)$ and different exposure times (1, 2, 4, 6, 8 and 10 hours). All stages of $T$. castaneum, eggs, pupae (One day age), larvae (1st, 3rd and 5th instar) and adults (female and male) were exposed to ozone by using ozone generator (ROHS Model GL-3189A, China) with the capacity of $600 \mathrm{Mg} \cdot \mathrm{hr}^{-1}$. The 


\section{Al-Emara et al. / Basrah J. Agric. Sci., 34(2), 240-252, 2021}

treatments of none ozone exposure were designated to be under similar experimental conditions at the same duration, but without the ozone treatment. The bioassay of each RFB stages was conducted in glass container $(5 \mathrm{~cm}$ diameter and $6 \mathrm{~cm}$ height) which covered with mesh. A drying and heating chamber (BINDER, Germany) with dimensions of (40 $\mathrm{cm}$ width, $38 \mathrm{~cm}$ height, $32 \mathrm{~cm}$ depth) was used as an insect exposure device20 which providing temperature fixed temperature as required in each bioassay. All openings of the exposure device was blocked with an exception of that connected to the ozone generator as well as the exit opening of the gas. Each treatment was carried out in three replications and at a rate of ten individuals for each replicate, pupae and whole adults were placed separately in plastic containers of 200 $\mathrm{ml}$ containing the aforementioned food medium, covered with Bored cloth type fabric and tightly tied with rubber bands. As for eggs, glass dishes with a diameter of $5 \mathrm{~cm}$ were used for this purpose. Ten individuals were used in each container at triplicates for each treatment. After the exposure to ozone, the freely exposed RFB's stages were incubated under the same colony conditions. The percentage of killing was calculated after 24 hours of incubation of the treatments in the incubator under the ideal temperature and humidity after each experiment. As for the eggs and pupae, the percentage of hatching is calculated after the time required for hatching has passed, as a maximum of 12 and 8 days for emergence pupae.

\section{Statistical analysis}

The hatchability and mortality ratios of the exposed RFB stages were transformed into an Arcsine transform to normalize changes in heterogeneous values, then corrected for control of mortality using the Schneider-Orelli formula (Püntener, 1981). The experiments were conducted with complete randomized design and the means were tested using ANOVA. The means were compared with the lowest LSD significant difference with 5\% probability level using the SPSS statistical program (IBM SPSS Statistics 24).

\section{Results}

Results of the RFB bioassay (Tables 1-4) for the ozonation showed different responses according to the temperatures and the exposure times to the ozone.

\section{Eggs}

The results of the survival depend on hatching found of RFB eggs (Table 1) showed that the hatching rate of eggs were significantly different at different temperatures and exposure times to ozone $(\mathrm{F}=1298.57$; $\mathrm{df}=72$; $\mathrm{p}<0.0001)$. The inhibition of hatching egg rates due to exposure to ozone were increased with the increase of the temperature. At the temperature of $30^{\circ} \mathrm{C}$, the high hatching egg rates was $96.7 \%$ after $1 \mathrm{~h}$ of the exposure to ozone and reduced up to $50 \%$ after $10 \mathrm{~h}$ of the exposure to the gas, compared to the 100 and 90 of hatching egg rates after 1 and $10 \mathrm{~h}$ at $30^{\circ}$ $\mathrm{C}$ in the untreated treatment, respectively. The hatching rate in exposed eggs to ozone for $1 \mathrm{~h}$ was $93.3 \%$ at $40^{\circ} \mathrm{C}$, while the rate was reduced to $36.7 \%$ after $10 \mathrm{~h}$ of the exposure to ozone at $40^{\circ} \mathrm{C}$; compared to untreated hatching rates, which did not decrease significantly with increased exposure to ozone at the same temperature $\left(40{ }^{\circ} \mathrm{C}\right)$. The highest hatching rate reduction $(0 \%)$ was examined at the treated treatments after $10 \mathrm{~h}$ at $45^{\circ} \mathrm{C}$, compared to $53.3 \%$ of hatching rates in the treated treatments after $1 \mathrm{~h}$ at the same tested temperature. 
Al-Emara et al. / Basrah J. Agric. Sci., 34(2), 240-252, 2021

Table (1): Hatchability percentages for $T$. castaneum eggs exposed to ozone gas $600 \mathrm{Mg} . \mathrm{hr}^{-1}$ at different temperatures and exposure times.

\begin{tabular}{|c|c|c|c|c|c|c|}
\hline \multicolumn{7}{|c|}{ Hatch rates of exposed eggs to ozone at different temperatures $\pm \mathrm{SE}$} \\
\hline \multirow{2}{*}{$\begin{array}{l}\text { Exposure } \\
\text { time (h) }\end{array}$} & \multicolumn{2}{|c|}{$35^{\circ} \mathrm{C}$} & \multicolumn{2}{|c|}{$40^{\circ} \mathrm{C}$} & \multicolumn{2}{|c|}{$45^{\circ} \mathrm{C}$} \\
\hline & Not exposed & Exposed & $\begin{array}{c}\text { Not } \\
\text { exposed }\end{array}$ & Exposed & $\begin{array}{c}\text { Not } \\
\text { exposed }\end{array}$ & Exposed \\
\hline 1 & $100 \pm 0.0 \mathrm{a}$ & $\begin{array}{c}96.7 \pm 3.3 \\
\mathrm{ab}\end{array}$ & $100.0 \pm 0.0 \mathrm{a}$ & $93.3 \pm 3.3 \mathrm{abc}$ & $70.0 \pm 5.8 \mathrm{~g}$ & $53.3 \pm 6.8 \mathrm{ij}$ \\
\hline 2 & $100 \pm 0.0$ aa & $90 \pm 0.0 \mathrm{de}$ & $96.7 \pm 3.3 \mathrm{ab}$ & $86.7 \pm 3.3 \mathrm{~cd}$ & $53.3 \pm 3.3 \mathrm{ij}$ & $33.3 \pm 8.8 \mathrm{kl}$ \\
\hline 4 & $\begin{array}{c}96.7 \pm 3.3 \\
\text { abab }\end{array}$ & $\begin{array}{c}83.3 \pm 3.3 \\
\text { de }\end{array}$ & $96.7 \pm 3.3 \mathrm{ab}$ & $80 \pm 0.0$ def & $36.7 \pm 3.3 \mathrm{k}$ & $26.7 \pm 8.81$ \\
\hline 6 & $93.3 \pm 3.3 \mathrm{abc}$ & $70 \pm 0.0 \mathrm{~g}$ & $\begin{array}{c}93.3 \pm 3.3 \\
\text { abc }\end{array}$ & $66.7 \pm 3.3 \mathrm{gh}$ & $\begin{array}{c}30.0 \pm 0.0 \\
\mathrm{kl}\end{array}$ & $6.7 \pm 3.3 \mathrm{n}$ \\
\hline 8 & $93.3 \pm 3.3 \mathrm{abc}$ & $\begin{array}{c}63.3 \pm 3.3 \\
\mathrm{gh}\end{array}$ & $90.0 \pm 0.0 \mathrm{de}$ & $60 \pm 5.8 \mathrm{hi}$ & $\begin{array}{c}16.7 \pm 3.3 \\
\mathrm{~m}\end{array}$ & $3.3 \pm 3.3 \mathrm{n}$ \\
\hline 10 & $90.0 \pm 0.0 \mathrm{~d}$ & $50 \pm 5.8 \mathrm{j}$ & $83.3 \pm 3.3 \mathrm{de}$ & $36.7 \pm 3.3 \mathrm{k}$ & $3.3 \pm 3.3 \mathrm{n}$ & $0.0 \pm 0.0 \mathrm{n}$ \\
\hline mean & 95.6 & 75.6 & 93.3 & 70.6 & 35 & 20.56 \\
\hline
\end{tabular}

The means followed by different letters have significant differences. As for the means followed by one of the same letters, they are not significant. Value of $\operatorname{LSD}(0.05)=6.96$

\section{Larvae}

In RFB larvae, mortalities due to ozone also increased with the increase of temperatures and exposure times to ozone $(F=4092.99$; df = 216; $p<0001$; Table 2). The complete mortality of $1^{\text {st }}, 3^{\text {rd }}$, and $5^{\text {th }}$ larval instars were reported after $10 \mathrm{~h}$ of exposure to ozone at $35^{\circ}$ C compared with untreated treatment $(0 \%)$. The larvae showed more susceptibility to ozone and the exposure time was reduced with increasing the temperatures; the mortality rates increased to $100 \%$ after 8 and $10 \mathrm{~h}$ of exposure to ozone at $40^{\circ} \mathrm{C}$ in $1^{\text {st }}, 3^{\text {rd }}$, and $5^{\text {th }}$ larval instars respectively compared to the untreated larval instars (13.3, 10 and 0\% mortality rates).
The exposure time was decreased more at $45^{\circ}$ $\mathrm{C}$ and led to a complete mortality after $2 \mathrm{~h}$ for the $1^{\text {st }}$ and $3^{\text {rd }}$, and $4 \mathrm{~h}$ for the $5^{\text {th }}$ instar compared to the mortality rates on larvae (80, 73.3 and $83.3 \%$ respectively) at the same temperature and duration with no exposure to ozone.

\section{Pupae}

The results also indicated that the exposure to ozone at temperatures of 30 and $40^{\circ} \mathrm{C}$ caused a significant ozone-dependent mortality in the pupae of RFB $(F=575.62 ; \mathrm{df}=72 ; p<0001$; 
Al-Emara et al. / Basrah J. Agric. Sci., 34(2), 240-252, 2021

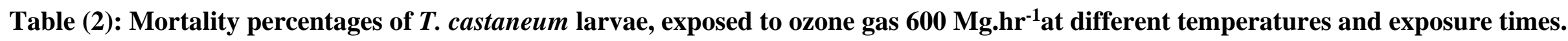

\begin{tabular}{|c|c|c|c|c|c|c|c|c|c|}
\hline \multirow{3}{*}{ Tem. } & \multirow{3}{*}{ Treatment } & \multirow{3}{*}{ Instars } & \multicolumn{6}{|c|}{ Mortality percentages $($ Means $\pm \mathrm{SE})$} & \multirow{3}{*}{ means } \\
\hline & & & \multicolumn{6}{|c|}{ Exposure time (h) } & \\
\hline & & & 1 & 2 & 4 & 6 & 8 & 10 & \\
\hline \multirow{6}{*}{$35^{\circ} \mathrm{C}$} & \multirow{3}{*}{$\begin{array}{c}\text { Not } \\
\text { exposed }\end{array}$} & $1^{\text {st }}$ & $0.0 \pm 0.0 \mathrm{u}$ & $0.0 \pm 0.0 \mathrm{u}$ & $0.0 \pm 0.0 \mathrm{u}$ & $0.0 \pm 0.0 \mathrm{u}$ & $0.0 \pm 0.0 \mathrm{u}$ & $0.0 \pm 0.0 \mathrm{u}$ & 0 \\
\hline & & $3^{\text {rd }}$ & $0.0 \pm 0.0 \mathrm{u}$ & $0.0 \pm 0.0 \mathrm{u}$ & $0.0 \pm 0.0 \mathrm{u}$ & $0.0 \pm 0.0 \mathrm{u}$ & $0.0 \pm 0.0 \mathrm{u}$ & $0.0 \pm 0.0 \mathrm{u}$ & 0 \\
\hline & & $5^{\text {th }}$ & $0.0 \pm 0.0 \mathrm{u}$ & $0.0 \pm 0.0 \mathrm{u}$ & $0.0 \pm 0.0 \mathrm{u}$ & $0.0 \pm 0.0 \mathrm{u}$ & $0.0 \pm 0.0 \mathrm{u}$ & $0.0 \pm 0.0 \mathrm{u}$ & 0 \\
\hline & \multirow{3}{*}{ Exposed } & $1^{\text {st }}$ & $6.7 \pm 3.3 \mathrm{st}$ & $13.3 \pm 3.3 \mathrm{r}$ & $36.7 \pm 3.3 n$ & $73.3 \pm 3.3 \mathrm{gh}$ & $93.3 \pm 3.3 b c$ & $100 \pm 0.0 \mathrm{a}$ & 53.89 \\
\hline & & $3^{\text {rd }}$ & $0.0 \pm 0.0 \mathrm{u}$ & $10 \pm 0.0 \mathrm{rs}$ & $26.7 \pm 3.3 p$ & $63.3 \pm 3.3 \mathrm{jk}$ & $90 \pm 0.0 \mathrm{~cd}$ & $100 \pm 0.0 \mathrm{a}$ & 48.33 \\
\hline & & $5^{\text {th }}$ & $0.0 \pm 0.0 \mathrm{u}$ & $3.3 \pm 3.3 \mathrm{t}$ & $20.0 \pm 0.0 q$ & $53.3 \pm 3.31$ & $80 \pm 5.8$ ef & $100 \pm 0.0 \mathrm{a}$ & 42.78 \\
\hline \multirow{6}{*}{$40^{\circ} \mathrm{C}$} & \multirow{3}{*}{$\begin{array}{c}\text { Not } \\
\text { exposed }\end{array}$} & $1^{\text {st }}$ & $0.0 \pm 0.0 \mathrm{u}$ & $0.0 \pm 0.0 \mathrm{u}$ & $0.0 \pm 0.0 \mathrm{u}$ & $3.3 \pm 3.3 \mathrm{t}$ & $6.7 \pm 3.3 \mathrm{st}$ & $13.7 \pm 3.3 \mathrm{r}$ & 3.89 \\
\hline & & $3^{\text {rd }}$ & $0.0 \pm 0.0 \mathrm{u}$ & $0.0 \pm 0.0 \mathrm{u}$ & $0.0 \pm 0.0 \mathrm{u}$ & $0.0 \pm 0.0 \mathrm{u}$ & $13.3 \pm 3.3 \mathrm{r}$ & $10.0 \pm 0.0 \mathrm{rs}$ & 2.22 \\
\hline & & $5^{\text {th }}$ & $0.0 \pm 0.0 \mathrm{u}$ & $0.0 \pm 0.0 \mathrm{u}$ & $0.0 \pm 0.0 \mathrm{u}$ & $0.0 \pm 0.0 \mathrm{u}$ & $0.0 \pm 0.0 \mathrm{u}$ & $0.0 \pm 0.0 \mathrm{u}$ & 0 \\
\hline & \multirow{3}{*}{ Exposed } & $1^{\text {st }}$ & $13.3 \pm 3.3 \mathrm{r}$ & $30.0 \pm 5.8 \mathrm{op}$ & $50.0 \pm 5.81$ & $80.0 \pm 0.0 \mathrm{ef}$ & $100 \pm 0.0 \mathrm{a}$ & $100 \pm 0.0 \mathrm{a}$ & 62.22 \\
\hline & & $3^{\text {rd }}$ & $6.7 \pm 3.3 \mathrm{st}$ & $43.3 \pm 3.3 \mathrm{~m}$ & $13.3 \pm 3.3 \mathrm{r}$ & $80.0 \pm 0.0 \mathrm{ef}$ & $100 \pm 0.0 \mathrm{a}$ & $100 \pm 0.0 \mathrm{a}$ & 58.89 \\
\hline & & $5^{\text {th }}$ & $0.0 \pm 0.0 \mathrm{u}$ & $13.3 \pm 3.3 r$ & $36.7 \pm 3.3 n$ & $70.0 \pm 5.8 \mathrm{hi}$ & $96.7 \pm 3.3 \mathrm{ab}$ & $100 \pm 0.0 \mathrm{a}$ & 52.78 \\
\hline \multirow{6}{*}{$45^{\circ} \mathrm{C}$} & \multirow{3}{*}{$\begin{array}{c}\text { Not } \\
\text { exposed }\end{array}$} & $1^{\text {st }}$ & $66.7 \pm 3.3 \mathrm{ij}$ & $80.0 \pm 5.8 \mathrm{ef}$ & $96.7 \pm 3.3 \mathrm{ab}$ & $100 \pm 0.0 \mathrm{a}$ & $100 \pm 0.0 \mathrm{a}$ & $100 \pm 0.0 \mathrm{a}$ & 90.56 \\
\hline & & $3^{\text {rd }}$ & $60.0 \pm 5.8 \mathrm{k}$ & $73.3 \pm 3.3 \mathrm{gh}$ & $90 \pm 0.0 \mathrm{~cd}$ & $100 \pm 0.0 \mathrm{a}$ & $100 \pm 0.0 \mathrm{a}$ & $100 \pm 0.0 \mathrm{a}$ & 87.22 \\
\hline & & $5^{\text {th }}$ & $53.3 \pm 3.31$ & $66.7 \pm 3.3 \mathrm{ij}$ & $83.3 \pm 3.3 \mathrm{e}$ & $96.7 \pm 3.3 \mathrm{ab}$ & $100 \pm 0.0 \mathrm{a}$ & $100 \pm 0.0 \mathrm{a}$ & 83.33 \\
\hline & \multirow{3}{*}{ Exposed } & $1^{\text {st }}$ & $80 \pm 0.0$ ef & $100 \pm 0.0 \mathrm{a}$ & $100 \pm 0.0 \mathrm{a}$ & $100 \pm 0.0 \mathrm{a}$ & $100 \pm 0.0 \mathrm{a}$ & $100 \pm 0.0 \mathrm{a}$ & 96.67 \\
\hline & & $3^{\text {rd }}$ & $76.7 \pm 3.3 \mathrm{fg}$ & $100 \pm 0.0 \mathrm{a}$ & $100 \pm 0.0 \mathrm{a}$ & $100 \pm 0.0 \mathrm{a}$ & $100 \pm 0.0 \mathrm{a}$ & $100 \pm 0.0 \mathrm{a}$ & 96.12 \\
\hline & & $5^{\text {th }}$ & $73.3 \pm 3.3 \mathrm{gh}$ & $96.7 \pm 3.3 \mathrm{ab}$ & $100 \pm 0.0 \mathrm{a}$ & $100 \pm 0.0 \mathrm{a}$ & $100 \pm 0.0 \mathrm{a}$ & $100 \pm 0.0 \mathrm{a}$ & 95 \\
\hline
\end{tabular}

The means followed by different letters have significant differences. As for the means followed by one of the same letters, they are not significant. Value of LSD (0.05) $=6.56$. 
Al-Emara et al. / Basrah J. Agric. Sci., 34(2), 240-252, 2021

Table (3): Mortality percentages of $T$. castaneum pupae exposed to ozone gas 600 Mg.hr-1 at different temperatures and exposure times.

\begin{tabular}{|c|c|c|c|c|c|c|}
\hline \multicolumn{5}{|c|}{ Mortality percentages (Means \pm SE) } \\
\hline $\begin{array}{c}\text { Exposure } \\
\text { time (h) }\end{array}$ & \multicolumn{2}{|c|}{$35^{\circ} \mathrm{C}$} & \multicolumn{2}{c|}{$40^{\circ} \mathrm{C}$} & \multicolumn{2}{c|}{$45^{\circ} \mathrm{C}$} \\
\hline & Not exposed & Exposed & Not exposed & Exposed & Not exposed & Exposed \\
\hline 1 & $0.0 \pm 0.0 \mathrm{k}$ & $0.0 \pm 0.0 \mathrm{k}$ & $0.0 \pm 0.0 \mathrm{k}$ & $0.0 \pm 0.0 \mathrm{k}$ & $3.3 \pm 5.8 \mathrm{k}$ & $60.0 \pm 0.0 \mathrm{~d}$ \\
\hline 2 & $0.0 \pm 0.0 \mathrm{k}$ & $0.0 \pm 0.0 \mathrm{k}$ & $0.0 \pm 0.0 \mathrm{k}$ & $6.7 \pm 3.3 \mathrm{jk}$ & $30.0 \pm 10.0 \mathrm{~g}$ & $80.0 \pm 5.8 \mathrm{c}$ \\
\hline 4 & $0.0 \pm 0.0 \mathrm{k}$ & $6.7 \pm 3.3 \mathrm{jk}$ & $0.0 \pm 0.0 \mathrm{k}$ & $13.3 \pm 3.3 \mathrm{ij}$ & $80.0 \pm 10.0 \mathrm{c}$ & $96.7 \pm 3.3 \mathrm{ab}$ \\
\hline 6 & $0.0 \pm 0.0 \mathrm{k}$ & $20 \pm 5.8 \mathrm{hi}$ & $3.3 \pm 5.8 \mathrm{k}$ & $26.7 \pm 3.3 \mathrm{gh}$ & $100 \pm 0.0 \mathrm{a}$ & $100 \pm 0.0 \mathrm{a}$ \\
\hline 8 & $0.0 \pm 0.0 \mathrm{k}$ & $40 \pm 5.8 \mathrm{f}$ & $13.3 \pm 5.8 \mathrm{ij}$ & $50 \pm 5.8 \mathrm{e}$ & $100 \pm 0.0 \mathrm{a}$ & $100 \pm 0.0 \mathrm{a}$ \\
\hline 10 & $0.0 \pm 0.0 \mathrm{k}$ & $60 \pm 5.8 \mathrm{~d}$ & $16.7 \pm 5.8 \mathrm{i}$ & $76.7 \pm 8.8 \mathrm{c}$ & $100 \pm 0.0 \mathrm{a}$ & $100 \pm 0.0 \mathrm{a}$ \\
\hline Mean & 0.0 & 21.1 & 5.6 & 28.9 & 68.9 & 89.4 \\
\hline
\end{tabular}

The means followed by different letters have significant differences. As for the means followed by one of the same letters, they are not significant. Value of $\operatorname{LSD}(0.05)=8.85$ 
Al-Emara et al. / Basrah J. Agric. Sci., 34(2), 240-252, 2021

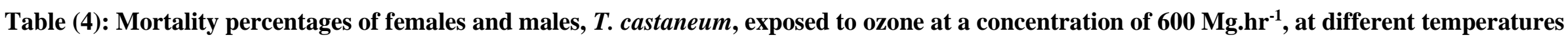
and exposure times.

\begin{tabular}{|c|c|c|c|c|c|c|c|c|c|}
\hline \multirow{3}{*}{ Tem. } & \multirow{3}{*}{ Treat. } & \multirow{3}{*}{ Sex } & \multicolumn{6}{|c|}{ Mortality percentages $($ Means \pm SE) } & \multirow{3}{*}{ mean } \\
\hline & & & \multicolumn{6}{|c|}{ Exposure time (h) } & \\
\hline & & & 1 & 2 & 4 & 6 & 8 & 10 & \\
\hline \multirow{3}{*}{$35^{\circ} \mathrm{C}$} & \multirow{2}{*}{$\begin{array}{c}\text { Not } \\
\text { expose } \\
\text { d }\end{array}$} & q & $0.0 \pm 0.0 \mathrm{r}$ & $0.0 \pm 0.0 \mathrm{r}$ & $0.0 \pm 0.0 \mathrm{r}$ & $0.0 \pm 0.0 \mathrm{r}$ & $0.0 \pm 0.0 \mathrm{r}$ & $0.0 \pm 0.0 \mathrm{r}$ & 0 \\
\hline & & $\hat{\jmath}$ & $0.0 \pm 0.0 \mathrm{r}$ & $0.0 \pm 0.0 \mathrm{r}$ & $0.0 \pm 0.0 \mathrm{r}$ & $0.0 \pm 0.0 \mathrm{r}$ & $0.0 \pm 0.0 \mathrm{r}$ & $0.0 \pm 0.0 \mathrm{r}$ & 0 \\
\hline & $\begin{array}{c}\text { Expose } \\
\mathrm{d}\end{array}$ & $\hat{0}$ & $3.3 \pm 3.3 \mathrm{r}$ & $20.0 \pm 5.8$ no & $30.0 \pm 0.0 \mathrm{~lm}$ & $46.7 \pm 3.3 \mathrm{ij}$ & $76.7 \pm 3.3 \mathrm{de}$ & $96.7 \pm 3.3 \mathrm{ab}$ & 45.57 \\
\hline \multirow{2}{*}{$40^{\circ} \mathrm{C}$} & \multirow{2}{*}{$\begin{array}{c}\text { Not } \\
\text { expose } \\
\text { d }\end{array}$} & $q$ & $0.0 \pm 0.0 \mathrm{r}$ & $0.0 \pm 0.0 \mathrm{r}$ & $0.0 \pm 0.0 \mathrm{r}$ & $0.0 \pm 0.0 \mathrm{r}$ & $6.7 \pm 3.3 \mathrm{qr}$ & $16.7 \pm 3.3$ op & 3.9 \\
\hline & & $\hat{0}$ & $0.0 \pm 0.0 \mathrm{r}$ & $0.0 \pm 0.0 \mathrm{r}$ & $0.0 \pm 0.0 \mathrm{r}$ & $6.7 \pm 3.3 \mathrm{qr}$ & $13.3 \pm 3.3 \mathrm{pq}$ & $30.0 \pm 7.8 \mathrm{~lm}$ & 8.33 \\
\hline \multirow{4}{*}{$45^{\circ} \mathrm{C}$} & \multirow{2}{*}{$\begin{array}{c}\text { Not } \\
\text { expose } \\
d\end{array}$} & q & $53.3 \pm 3.3 \mathrm{hi}$ & $76.7 \pm 3.3 \mathrm{de}$ & $93.3 \pm 3.3 \mathrm{ab}$ & $100 \pm 0.0 \mathrm{a}$ & $100 \pm 0.0 \mathrm{a}$ & $100 \pm 0.0 \mathrm{a}$ & 87.22 \\
\hline & & $\hat{0}$ & $63.3 \pm 3.3 \mathrm{fg}$ & $83.4 \pm 3.3 \mathrm{~cd}$ & $96.7 \pm 3.3 \mathrm{ab}$ & $100 \pm 0.0 \mathrm{a}$ & $100 \pm 0.0 \mathrm{a}$ & $100 \pm 0.0 \mathrm{a}$ & 90.57 \\
\hline & \multirow{2}{*}{$\begin{array}{c}\text { Expose } \\
\mathrm{d}\end{array}$} & q & $73.3 \pm 3.3 \mathrm{e}$ & $93.3 \pm 3.3 \mathrm{ab}$ & $100 \pm 0.0 \mathrm{a}$ & $100 \pm 0.0 \mathrm{a}$ & $100 \pm 0.0 \mathrm{a}$ & $100 \pm 0.0 \mathrm{a}$ & 94.43 \\
\hline & & $\hat{0}$ & $83.3 \pm 3.3 \mathrm{~cd}$ & $100 \pm 0.0 \mathrm{a}$ & $100 \pm 0.0 \mathrm{a}$ & $100 \pm 0.0 \mathrm{a}$ & $100 \pm 0.0 \mathrm{a}$ & $100 \pm 0.0 \mathrm{a}$ & 97.22 \\
\hline
\end{tabular}

The means followed by different letters have significant differences. As for the means followed by one of the same letters, they are not significant. Value of LSD $(0.05)=7.76$ 


\section{Al-Emara et al. / Basrah J. Agric. Sci., 34(2), 240-252, 2021}

Table 3). The mortalities were 60 and 76.7 after $10 \mathrm{~h}$ of exposure to ozone, respectively in comparison with to the untreated treatments $(0$ and $16.7 \%$ respectively). Whereas, the mortality rate increased $96.7 \%$ and $100 \%$ after 4 and $6 \mathrm{~h}$ of exposure to ozone at $45^{\circ} \mathrm{C}$, compared to mortalities of 80 and $100 \%$ respectively in the untreated treatment at the same duration of exposure to the gas and temperature.

\section{Adults}

There was a significant ozone effect on overall mortalities of females and males of $T$. castaneum ( $F=1868.3$; df $=144 ; p<0001)$. Mortalities increased with the increase of temperatures and exposure times to ozone ( $F=$ 334.9; df $=5 ; p<0001$ ) (Table 4). The mortality rate of RFB females and males increased significantly and reached the highest rates of 90 and $96.7 \%$ after $10 \mathrm{~h}$ of exposure to ozone at $35^{\circ} \mathrm{C}$, respectively compared to the untreated treatments, whereas the mortality rates of females and males were $0 \%$ after $10 \mathrm{~h}$ at $35^{\circ} \mathrm{C}$. Females and males of T. castaneum became more susceptible to ozone with the increase of the temperatures; the mortality rates of adults increased to $100 \%$ compared to the untreated (16.7\% of $q$ and $30.0 \%$ of $\left.\delta^{\lambda}\right)$ after $10 \mathrm{~h}$ at $40^{\circ} \mathrm{C}$. Moreover, the exposure time was decreased with increasing the temperature; exposed adults to ozone at the temperature of $45^{\circ} \mathrm{C}$ caused the complete mortality after $2 \mathrm{~h}$ for the males and $4 \mathrm{~h}$ for the females compared to the untreated adults (96.7 $\%$ of $q$ and $83.4 \%$ of $\AA$ ) at the same temperature and duration with no exposure to the gas.

\section{Discussion}

The mortality and hatch egg rates of RFB $T$. castaneum infesting wheat were linked to the ozonation (approximately of $600 \mathrm{mg} . h o u r^{-1}$ ); the rates were increased with increasing of the temperature and the exposure time to ozone. When ozone was applied at the lowest examined temperature $\left(35^{\circ} \mathrm{C}\right)$ for $10 \mathrm{~h}$, complete mortality or few survivals of RFB were recorded in the susceptible stages (larvae and adults) compared to zero mortalities in control treatments; whereas, a $50 \%$ or more survivals were reported in less susceptible stages (eggs and pupae). Additionally, the ozone treatment at $40^{\circ} \mathrm{C}$ for $10 \mathrm{~h}$ caused complete mortality at all stages with an exception of eggs and pupae. Subsequently, the full mortality of adults, pupae and larvae stages were recorded at 4,6 , and 4 h exposure of ozone at $45^{\circ}$ respectively, but the exposure for $10 \mathrm{~h}$ led to entire mortalities at all stages of RFB. A few other studies have recorded the effect of ozonation with heating on the stored grain insects; Sabeat (2017) revealed the effectiveness of using ozone gas (400 mg.h ${ }^{-1}$ ) with increasing of temperature levels and exposure times against larvae and adults of $T$. castaneum. Sabit \& Sabr (2015) indicated that applying ozone gas with heat increased the mortality of Trogoderma granarium stages.

Insects respond to ozone as a toxic chemical and as a reaction they breathe intermittently to reduce their damage, however it may cause oxidative tissue damage even at low concentrations (Hetz \& Bradley, 2005). The effect of ozone on the respiration of insects, Sitophilus oryzae, Rhyzopertha dominica and T. castaneum, occurs in two stages. The first includes less respiration when under the influence of ozone and in the second stage it rises with continuing treatment, the ozone gas enters directly into the insect cavity through the respiratory system and then diffuses to the rest of the tissues through the air tubes that bifurcate throughout the body to deliver oxygen mainly to the mitochondria (Lu et al., 2009; Harrison et al., 2012). The circulatory system can also participate in gas exchange by 


\section{Al-Emara et al. / Basrah J. Agric. Sci., 34(2), 240-252, 2021}

ventilating the bronchial system (Wasserthal, 1996; Miller, 1997). Because carbon dioxide can diffuse more easily through tissues compared to oxygen (Schmitz \& Perry, 1999), therefore, an imbalance occurs in the gases within the insect's tissues between oxygen and carbon dioxide, which leads to an increase in breathing as well as the heart rate. The ozone penetrates the cell membranes, heading directly to the mitochondria, where it oxidizes energy compounds, causing starvation of the insect with a high drainage of ATP energy compounds, where signs of stopping movement and vital activities that end in the insect's death (Harak et al., 1999). Ozone and its degradation products into free radicals (reactive oxygen species) interact directly with proteins, DNA, and polyunsaturated fatty acid double bonds and destroy biomolecules such as DNA (Hermes-Lima, 2004; Korsloot et al., 2004).

The optimization of the efficiency of ozonation procedure with rising temperature have been recorded in this study, that may be attributed to ozone degradation which is accelerated at high temperature (Kim, 1998; Itoh et al., 2020). Overall, the results of the ozonation application showed the efficacy of ozone on RFB mortality and the potential of temperature as a vital factor for application of ozonation for RFB control. Due to the difference in the thickness and nature of the body wall between the different roles of the same type of insect, it leads to the difference in the killing rates when exposed to high heat, and the difference in sensitivity between the larval stages may be due to the same reason, as the high killing rates are explained in the different roles of the insect in the treatment (ozone + heat and with shorter periods of time than treating heat alone to two main factors, the mechanism of opening the insect's respiratory stomata due to lack of oxygen and thus rapidly losing water from its body as a result of the other factor, heat (Wigglesworth, 1972). The high temperature affects the protoplasm and the insects die when the phospholipids layer in the cell membranes becomes more liquid, in addition to the structure of proteins and thus the enzymes are adversely affected by the high temperature, and the high temperature also affects the $\mathrm{pH}$, which negatively affects the medium in which these enzymes work. Water stress is a critical factor between 35 and $43{ }^{\circ} \mathrm{C}$ (Papanikolaou $e t$ al., 2018). As for eggs and pupae, they were more tolerant to ozone than larvae and adults, and this was due to the barriers that prevent ozone from reaching the target sites, and ozone needs to cross the outer shell of the egg to come into contact with the insect's embryo, as well as the reduced respiration rate and metabolism of insect eggs and pupae (McDonough et al., 2011).

Holmstrup et al. (2011) showed that ozone causes an overall decrease in metabolism (including transcription of genes to detoxify reactive oxygen species due to respiratory vents being closed for longer than normal in response to the presence of ozone). As for Sabat \& Sabr (2015), they showed that ozone breaks down cell membranes through the process of oxidation and forms $\left(\mathrm{H}_{2} \mathrm{O}_{2}\right), \mathrm{OH}$ and $\mathrm{O}_{2}$ and changes their chemical composition by affecting the nature of the phospholipid layer.

\section{Conclusions}

The results indicated that ozone gas could be one of the important alternatives to the pesticides used in controlling the RFB, especially fumigants, and that the heat could be used as a synergistic agent with ozone, as ozone could be used as a component of the integrated management of stored insect pests. The results also showed that the temperature 


\section{Al-Emara et al. / Basrah J. Agric. Sci., 34(2), 240-252, 2021}

was inversely proportional to the time required to kill all the roles of the insect, while both the temperature and time were directly proportional to the killing rates, and despite the sensitivity of the red flour beetle adults to ozone gas in general, the males were more sensitive than the females, while the eggs and the pupae required more time. To reach the percentage of $100 \%$ perdition of the remaining roles.

\section{Acknowledgements}

The authors thank Prof. Dr. Razzaq S. Akel and Assis. Prof. Dr. Hana Hani Al-Saffar, Research Centre and Museum of Natural History, University of Baghdad for classifying the insect.

\section{Conflicts of interest}

The authors declare that they have no conflict of interests.

\section{ORCID}

A. Alyousuf: 0000-0002-7352-0168

M. H. Abass: 0000-0002-4697-4076

M. Al-Emara: 0000-0003-2531-3233

\section{References}

Aboelhadid, S. M., \& Youssef, I. M. (2021). Control of red flour beetle (Tribolium castaneum) in feeds and commercial poultry diets via using a blend of clove and lemongrass extracts. Environmental Science and Pollution Research, 28, 30111-30120. https://doi.org/10.1007/s11356-021-12426-7

Beeman, R. W., Haas, S., Friesen, K., Shooting, T., \& Prevention, T. (2009). Beetle wrangling tips: An introduction to the care and handling of Tribolium castaneum.

Available

online. https://www.ars.usda.gov/plainsarea/mhk/cgahr/spieru/docs/tribolium-stockmaintenance/

Fedina, T. Y., \& Lewis, S. M. (2006). Proximal traits and mechanisms for biasing paternity in the red flour beetle Tribolium castaneum (Coleoptera: Tenebrionidae). Behavioral Ecology and
Sociobiology, 60,

844-853. https://doi.org/10.1007/s00265-006-0228-7

Forney, C. F., Song, J., Hildebrand, P. D., Fan, L., \& McRae, K. B. (2007). Interactive effects of ozone and 1-methylcyclopropene on decay resistance and quality of stored carrots. Postharvest Biology and Technology, 45, 341-348. https://doi.org/10.1016/j.postharvbio.2007.03.006

Harak, M., Lamprecht, I., Kuusik, A., Hiiesaar, K., Metspalu, L., \& Tartes, U. (1999). Calorimetric investigations of insect metabolism and development under the influence of a toxic plant extract. Thermochimica acta, 333, 39-48. https://doi.org/10.1016/S0040-6031(99)00093-3

Harrison, J. F., Woods, H. A., \& Roberts, S. P. (2012). Ecological and environmental physiology of insects, Vol. 3. Oxford University Press. https://doi.org/10.1093/acprof:oso/9780199225941.001 .0001

Hermes-Lima, M. (2004). Oxygen in biology and biochemistry: role of free radicals. Functional Metabolism: Regulation and Adaptation, 1, 319-66. https://doi.org/10.1002/047167558X.ch12

Hetz, S. K., \& Bradley, T. J. (2005). Insects breathe discontinuously to avoid oxygen toxicity. Nature, 433, 516-519 https://doi.org/10.1038/nature03106

Holmstrup, M., Sørensen, J. G., Heckmann, L. H., Slotsbo, S., Hansen, P., \& Hansen, L. S. (2011). Effects of ozone on gene expression and lipid peroxidation in adults and larvae of the red flour beetle (Tribolium castaneum). Journal of Stored Products Research, 47, 378-384. https://doi.org/10.1016/j.jspr.2011.07.002

Iram, N., Arshad, M., \& Akhter, N. (2013). Evaluation of botanical and synthetic insecticide for the control of Tribolium castaneum (Herbst) (Coleoptera: Tenebrionidae). BioAssay, 8, 1-10. https://www.seb.org.br/biosay/arquivos/journals/1/ articles/117/public/117-765-2-PB.pdf

Işikber, A. A., \& Öztekin, S. (2009). Comparison of susceptibility of two stored-product insects, Ephestia kuehniella Zeller and Tribolium confusum $\mathrm{du}$ Val to gaseous ozone. Journal of Stored Products Research, 45, 159-164. https://doi.org/10.1016/j.jspr.2008.12.003

Itoh, H., Taguchi, M., \& Suzuki, S. (2020). Thermal decomposition of ozone at high temperature leading to ozone zero phenomena. Journal of 


\section{Al-Emara et al. / Basrah J. Agric. Sci., 34(2), 240-252, 2021}

Physics D: Applied Physics, 53, 185206. https://orcid.org/0000-0002-0517-5817

Karunakaran, C., Jayas, D. S., \& White, N. D. G. (2004). Identification of wheat kernels damaged by the red flour beetle using X-ray images. Biosystems Engineering, 87, $267-$ 274.https://doi.org/10.1016/j.biosystemseng.2003. 12.002

Kells, S. A., Mason, L. J., Maier, D. E., \& Woloshuk, C. P. (2001). Efficacy and fumigation characteristics of ozone in stored maize. Journal of Stored Products Research, 37, 371-382. https://doi.org/10.1016/S0022-474X(00)00040-0

Khadre, M. A., Yousef, A. E., \& Kim, J. G. (2001). Microbiological aspects of ozone applications in food: a review. Journal of Food Science, 66, 12421252. https://doi.org/10.1111/j.13652621.2001.tb15196.x

Kim, J.-G. (1998). Ozone, as an antimicrobial agent in minimally processed foods (Doctoral dissertation, The Ohio State University). http://rave.ohiolink.edu/etdc/view?acc_num=osu1 120751688

Kopacki, M., Pawłat, J., Skwaryło-Bednarz, B., Jamiołkowska, A., Stępniak, P. M., Kiczorowski, P., \& Golan, K. (2021). Physical Crop Postharvest Storage and Protection Methods. Agronomy, 11, 116. https://doi.org/10.3390/agronomy11010093

Korsloot, A., van Gestel, C. A., \& Van Straalen, N. M. (2004). Environmental stress and cellular response in Arthropods. CRC Press. Boca Raton. https://www.cabdirect.org/cabdirect/abstract/2005 3055713

Kumar, D., \& Kalita, P. (2017). Reducing postharvest losses during storage of grain crops to strengthen food security in developing countries. Foods, 6, 8. https://doi.org/10.3390/foods6010008

Lu, G., Ocola, L. E., \& Chen, J. (2009). Reduced graphene oxide for room- temperature gas sensors. Nanotechnology, 20, 445502. https://doi.org/10.1088/0957-4484/20/44/445502

Mariadoss, A., \& Umamaheswari, S. (2020). Feeding preference and development of red flour beetle, Tribolium castaneum (Herbst.) in different rice varieties Stored for public distribution in India. Journal of Experimental Zoology, India, 23, 265-268. http://www.connectjournals.com/jez
Mason, L. J., Woloshuk, C. P., Mendoza, F., Maier, D. E., \& Kells, S. A. (2006). Ozone: A new control strategy for stored grain. In Proceedings of the 9th International Working Conference on Stored Product Protection, 15-18. http://bru.gmprc.ksu.edu/.../6314.pdf

McDonough, M. X., Mason, L. J., \& Woloshuk, C. P. (2011). Susceptibility of stored product insects to high concentrations of ozone at different exposure intervals. Journal of Stored Products Research, 47, 306-310. https://doi.org/10.1016/j.jspr.2011.04.003

Mendez, F., Maier, D. E., Mason, L. J., \& Woloshuk, C. P. (2003). Penetration of ozone into columns of stored grains and effects on chemical composition and processing performance. Journal of Stored Products Research, 39(1), 33-44. https://doi.org/10.1016/S0022-474X(02)00015-2

Miller, T. A. (1997). Control of circulation in insects. General Pharmacology: The Vascular System, 29(1), 23-38. https://doi.org/10.1016/S0306-3623(96)00522-8

Papanikolaou, N. E., Kavallieratos, N. G., Boukouvala, M. C., \& Malesios, C. (2018). Do temperature, relative humidity and interspecific competition alter the population size and the damage potential of stored-product insect pests? A hierarchical multilevel modeling approach. Journal of Thermal Biology, 78,

415-422. https://doi.org/10.1016/j.jtherbio.2018.10.022

Pretty, J., \& Bharucha, Z. P. (2015). Integrated pest management for sustainable intensification of agriculture in Asia and Africa. Insects, 6, 152182. https://doi.org/10.3390/insects6010152

Pimentel, M. A. G., Faroni, L. R. D. A., Tótola, M. R., \& Guedes, R. N. C. (2007). Phosphine resistance, respiration rate and fitness consequences in storedproduct insects. Pest Management Science: (formerly Pesticide Science), 63, 876-881. https://doi.org/10.1002/ps.1416

Rees, D. P. (2004). Insects of stored products. CSIRO publishing Collingwood Victoria, Australia, 181pp. https://doi.org/10.1071/9780643101128

Sabeat, F. A. (2017). The efficiency of using ozone gas and heat to control larvae and adult stage of red flour beetle, Tribolium castaneum (Herbst) (Coleoptera: Tenebrionidae). Baghdad Science Journal,

14 ,

677-681. 


\section{Al-Emara et al. / Basrah J. Agric. Sci., 34(2), 240-252, 2021}

https://doi.org/10.21123/bsj.14.4.677-681 （In Arabic?).

Sabit, F. A., \& Sabr, S. H. (2015). Evaluation of the efficiency of the use of ozone gas and temperatures in the control of the moving roles of the capillary grain beetle (Khabra) laboratory Trogoderma granarium Everts (Coleoptera: Dermestidae). Iraqi Journal of Sciences, 56, 1904-1910. ttps://www.iasj.net/iasj/article/105671

Schmitz, A., \& Perry, S. F. (1999). Stereological determination of tracheal volume and diff using capacity of the tracheal walls in the stick insect Carausius morosus (Phasmatodea, Lonchodidae). Physiological and Biochemical Zoology, 72, 20518. https://doi.org/10.1086/316655

Seyedabadi, E., Aran, M., \& Moghaddam, R. M. (2021). Application of ozone against the larvae of Plodia interpunctella (Hübner) and its impacts on the organoleptic properties of walnuts. Journal of Food Protection, $\quad 84, \quad$ 147-151. https://doi.org/10.4315/JFP-20-331

Shiferaw, B., Smale, M., Braun, H. J., Duveiller, E., Reynolds, M., \& Muricho, G. (2013). Crops that 422 feed the world 10. Past successes and future challenges to the role played by wheat in 423 global food security. Food Security, 5, 291-317. https://doi.org/10.1007/s12571-013-0263-y

Sial, M. U., Saeed, Q., Rahman, S., \& Qayyum, M. F. (2017). Upshot of food add-ons on the life history and development of Tribolium castaneum (Herbst) (Coleoptera: Tenebrionidae). African Entomology, 25, 37-41. https://doi.org/10.4001/003.025.0037

Sousa, A. D., Faroni, L. D. A., Guedes, R. N. C., Tótola, M. R., \& Urruchi, W. I. (2008). Ozone as a management alternative against phosphineresistant insect pests of stored products. Journal of Stored Products Research, 44, 379-385. https://doi.org/10.1016/j.jspr.2008.06.003
Tefera, T., Kanampiu, F., De Groote, H., Hellin, J., Mugo, S., Kimenju, S., Beyene, Y., Boddupalli, P.M., Shiferaw, B., \& Banziger, M. (2011). The metal silo: An effective grain storage technology for reducing post-harvest insect and pathogen losses in maize while improving smallholder farmers' food security in developing countries. Crop Protection, 30, 240-245. https://doi.org/10.1016/j.cropro.2010.11.015

Tiwari, B. K., Brennan, C. S., Curran, T., Gallagher, E., Cullen, P. J., \& Donnell, C. P. (2010). Application of ozone in grain processing. Journal of Cereal Science, $\quad 51, \quad 248-255$. https://doi.org/10.1016/j.jcs.2010.01.007

Wasserthal, L. T. (1996). Interaction of circulation and tracheal ventilation in holometabolous insects. Advances in Insect Physiology, 26, 297-351. https://doi.org/10.1016/S0065-2806(08)60033-8

Wei, K., Zhou, H., Zhou, T., \& Gong, J. (2007). Comparison of aqueous ozone and chlorine as sanitizers in the food processing industry: Impact on fresh agricultural produce quality. Ozone: Science and Engineering, 29, 113-120. https://doi.org/10.1080/01919510601186592

Whalon, M. E., Motasanchez D., \& Holling Worth, R. M., (2008). Global pesticide resistance in Arthropods. CABI Publication, 208pp. https://doi.org/10.1079/9781845933531.0000

Wigglesworth, V. B. (1972). The Principles of Insect Physiology. $\quad$ Dordrecht: Springer. https://doi.org/10.1007/978-94-009-5973-6

Juárez, Z. N., Bach, H., Bárcenas-Pozos, M. E., \& Hernández, L. R. (2021). Impact of the persistence of three essential oils with antifungal activities on stored wheat grains, flour, and baked products. Foods, 10 , 213. https://doi.org/10.3390/foods10020213 
Tribolium castaneum (Herbst) فعالية الأوزون ضد خنفساء الطحين الحمراء عند مستويات حرارة وأوقات تعرض مختلفة (Coleoptera: Tenebrionidae)

محمد صبري الامارة1 وعقيل عدنان اليوسف2 ومحمد حمزة عباس2

1الثركة العامة لتجارة المواد الغذائية، وزارة التجارة، العراق

2_قسم وقاية النبات، كلية الزر اعة، جامعة البصرة، العراق

المستخلص: أجري البحث مختبريا لمعرفة فاعلية غاز الأوزون برفقة الحرارة او الحرارة المنفردة عند (45،45، 45، مْ لكالا

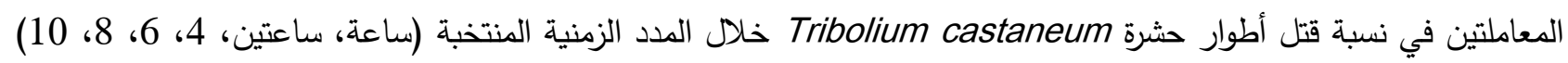

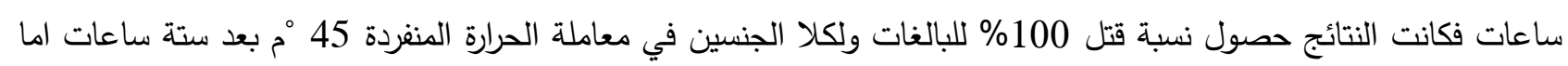

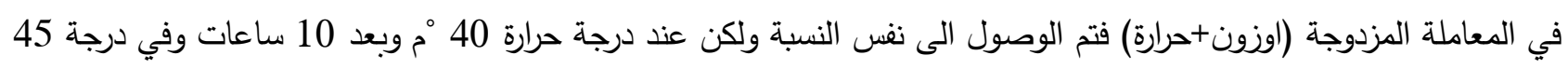

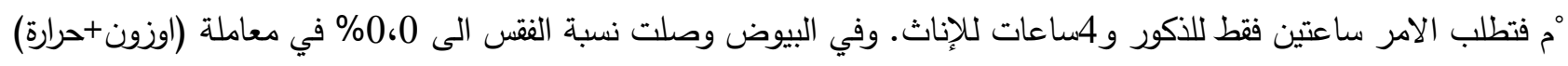

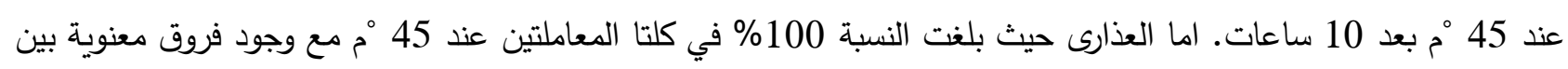

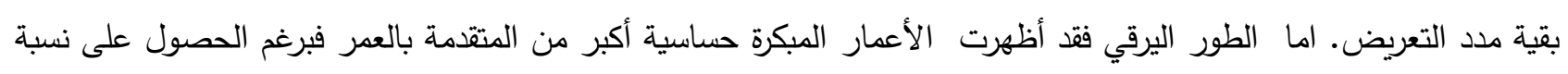

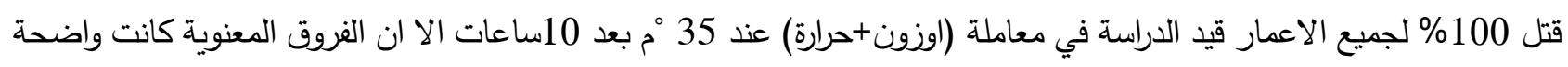

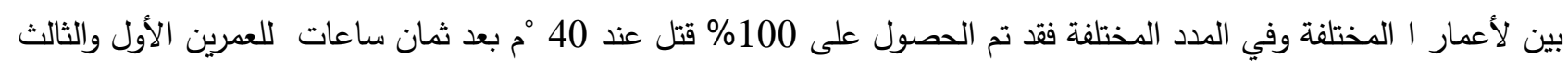

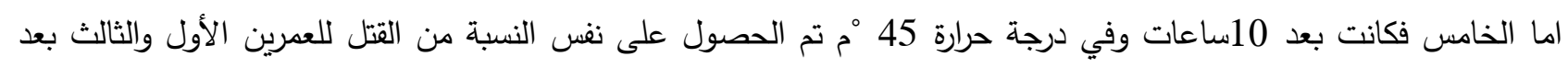

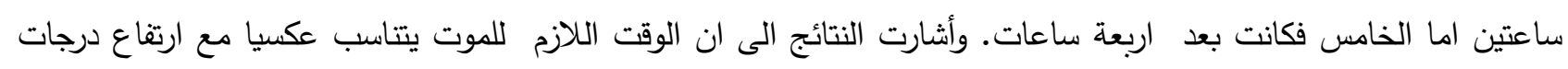

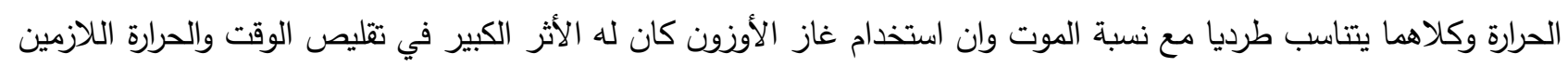
للموت. الكلمات المفتاحية: الأوزون، Tribolium castaneum، خنفاء الدقيق الصدئية، مكافحة غير كيميائية. 